\title{
EFFECT OF PALM OIL SUPPLEMENTATION ON CARCASS YIELD AND FATTY ACID COMPOSITION OF GROWING RABBITS.
}

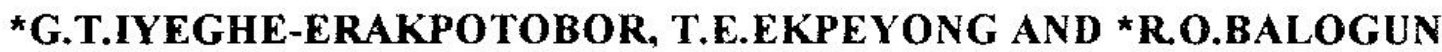 \\ Department of Animal Science, Lniversity of Ibalan, Ibadan \\ *National Animal Production Research Institute, Ahmadu Bello University, Shika-Zaria.
}

Received 02 November 1996; Accepted 23 May 1997.

\begin{abstract}
A 12 week feeding trial was conducted to evaluate the effect of palm oil (PO) supplementation at $0 \%$ (control), $3 \%$ or $5 \%$ levels on carcass yields and fatty acid composition of organs of growing rabbits. Results obtained showed that palm oil supplementation did not significantly affect $(P>0.05)$ carcass and organ yields. Percent analysis however showed that in the heart, myristic acid was highest in the control diet $(78.58 \%)$, lauric acid in $3 \%$ PO $(41.56 \%)$ and stearic acid in $5 \%$ PO $(84.43 \%)$ groups. In the kidney, there was increased level of palmitic (1.30-57.06\%)but decreased levels of myristic $(43.41-0.51 \%)$ and oleic acids $(9.26-8.08 \%)$. There were detectable levels of raprylic, linoleic and arachidonic acids in rabbits fed PO diets compared to none in the control group. On the other hand, there were detectable levels of stearic and lauric acids in the control group but none in the PO groups. In the liver, only lauric, stearic and myristic acids were detected, with the latter not detected in the liver of cor.trol group. Three rabbits on the control diet died as a result of speticaemia. It was concluded from this study that $P O$ seemed to affect organ fatty acid composition but not on weight of organs. The effect on fatty acid composition was however, not consistent.
\end{abstract}

Key words: Rabbit, palm oil, carcass, organs, fatty acid.

\section{INTRODUCTION}

Fats are essential in ensuring adequate utilisation of nutrients for growth and reproduction (Sell and Owings, 1981; Beynan, 1988). Fats could reduce intake but at the same time increase rate of weight gain (Eshiett et al., 1979; lyeghe and Ekpenyong, 1990). Other advantages of fats in the diets include enhancing the absorption of vitamin $\mathrm{A}$, sparing action on vitamin $D$ and developement of immune response (Jezkova and Petz, 1976).

Oils of diflerent types are good sources of fat and type of dietary fat have been shown to influence pertomance of rabbits (Beynan, 1988; Iyeghe and Ekpenyong, 1990). Apart from their high content of tats, oils are also good sources of high energy in the diet. High concentration of energy in the diet of rabbits increases the caloric density of the diet (Sell and Owings, 1981) and could increase carcass and organ yietds or affect the fatty acid composition of tissues and organs in the body. Eshiett et al., (1979) reported slight increase in carcass yield and reducion in kidney and liver weights wit increase in energy concentration of rabbit diet. Changes in organ fatty acid composition vary with source of fat, level of fat, animal species and age (Williams $e t$ al., 1968 Sabine et al., 1969; Vodovar et. al., 1973; Bashid et al., 1973; Dramer et al., 1975; Puthzath and Alamela, 1977).

Palm oil is the cheapest and most readily available oil in Nigeria. It is higher in energy and fatty acids compared to other oils. It is also a good source of essential fatty acids. which are important in immune response (Jezkova and Peiz, 1976). This study determined the effect of palm oil supplementation on carcass yield and fatty acid composition of growing rabbits in the humid tropics.

\section{MATERIALS AND METHODS}

This study was conducted at the University of Ibadan, Nigeria farm. Twenty four growing crossbred rabbits (average body weight of $540 \mathrm{~g}$ ) were bought from an open market and were randomly allocated to three treatment diets with palm oil (PO) supplementation at $0 \%$ (control), $3 \%$ or $5 \%$. The feed and proximate composition of the experimental diets have been reported by 
TABLE 1: COMPOSITION OF EXPERIMENTAL, DIETS

\begin{tabular}{|c|c|c|c|}
\hline \multirow[b]{2}{*}{ Ingredient (g) } & \multirow[b]{2}{*}{0} & \multicolumn{2}{|c|}{ Palm oil supplementation (\%) } \\
\hline & & 3 & $\cdot 5$ \\
\hline Com offal & 19.99 & 46.35 & 64.60 \\
\hline Palm kernel meal & 76.51 & $43.0 \mathrm{r}$ & 20.13 \\
\hline Bone meal & 3.00 & 3.00 & 3.00 \\
\hline Palm oil & - & 3.00 & 5.00 \\
\hline Blood meal & - & 4.14 & 6.97 \\
\hline Salt & 0.25 & 0.25 & 0.25 \\
\hline Vit/min/ premix & 0.25 & 0.25 & 0.25 \\
\hline \multicolumn{4}{|c|}{ Calculated composition: } \\
\hline Energy (kcal ME/kg) & 2313.50 & 2345.00 & 2365.00 \\
\hline Crude protein (\%) & 18.01 & 17.99 & 18.00 \\
\hline Crude fibre (\%) & 8.00 & 6.45 & 5.39 \\
\hline
\end{tabular}

(Iyeghe and Ekpeyong, 1999)

"Contains per $\mathrm{Kg} ; 3,000,000 \mathrm{IU}$ vitamin $\mathrm{A} ; 600,00 \mathrm{IU}$ vitamin $\mathrm{D}_{3} ; 4,000 \mathrm{mg}$ vitamin $\mathrm{E} ; 600 \mathrm{mg}$ vitamin $\mathrm{K}_{3} ; 1,200 \mathrm{mg}$ vitamin $B_{2} ; 2,000 \mathrm{mg}$ vitamin $B_{3} ; 1.2 \mathrm{mg}$ vitamin $B_{12} ; 6,000 \mathrm{mg}$ niacin, $84,000 \mathrm{mg}$ Chlorine;24,000mg Mn; $800 \mathrm{mg}$ Fe; $16,000 \mathrm{mg} \mathrm{Cu} ; 18,000 \mathrm{mg} \mathrm{Zn} ; 500 \mathrm{mg}$ lodine; $48 \mathrm{mg}$ Se and antioxidant(BHT).

Iyeghe and Ekpenyong (1990) and is shown in Tables 1 and 2. Rabbits were kept in individual cages and experimental diets were fed once daily in the moming. Green forage was provided once daily, in the evening to all the experimental animals. Water was also provided ad libitum. One rabbit fed 5\% PO diet did in the seventh week of this study as a result of paralysis from broken spine and subsequent urinary incontinence.

At the end of the 12 - week feeding period, two male rabbits from each treatment group were weighed and slaughtered. The rabbtis were skinned and the carcass, liver, kidney, heart, head, intestines and skin weighed to determine their yields, expressed as percentage of the liveweight immediately before slaughter. The kidney, liver and heart were dried of blood with soft tissue paper, weighed and then stored until required for extraction and analysis.

Extractions of total lipids in the various organs were carried out at the Nizerian Stored Products Research Institute (NSPRI), Ibadan, using the procedure of AOAC, 1985). Extraction was done for five hours using a mixture of methanol: chloroform $(1: 1 \mathrm{v} / \mathrm{v})$ in a soxhlet apparatus, electrothermal extraction unit. Extracted lipids, in the mixture of methanol/chloroform were then stored in a deep freezer at a temperature of $-12^{\circ} \mathrm{C}$. Methylation and gas liquid chromatography (GLC) analysis was carried out at the Biochemistry Department of the Nigerian Institute for Oil Palm Research (NIFOR), Benin (James, 1960). Methyl esters were prepared by refluxing the lipids in a methanol: concentrated sulphuric acid mixture $(9: 1 \mathrm{v} / \mathrm{v})$, in a sand bath for one hour. The mixture was allowed to cool slightly and poured into a fractionating flask and

TABLE 2: PROXIMATE COMPOSITION OF EXPERIMENTAL DIETS

\begin{tabular}{llll}
\hline Constituent(g/100g dry matter) & control & $\begin{array}{c}\text { Diet } \\
\text { 3\% palm oil }\end{array}$ & $5 \%$ palm oil \\
\hline Dry matter & 97.00 & 98.00 & 96.00 \\
Crude fibre & 6.18 & 10.20 & 15.62 \\
Crude protein & 19.12 & 19.02 & 17.87 \\
Ether extract & 1.03 & 4.08 & 6.25 \\
Ash & 9.79 & 9.59 & 10.10 \\
Nitrogen free & $6 x .88$ & 57.11 & 50.16 \\
\hline
\end{tabular}


$10 \mathrm{ml}$ Hexane added. The mixture was shaken thoroughly and allowed to stand for 3 minutes. The methyl esters in hexane was collected and heated for 3 - 4 minutes. Onemg anhydrous Sodium sulphate $\left(\mathrm{Na}_{2} \mathrm{SO}_{4}\right)$ was added to the methyl esters. This mixture was then passed through the GLC (model Pye 104), with the following setting: flow rate $35 \mathrm{mis} / \mathrm{minute}$, flame ionization detector, $185^{\circ} \mathrm{C}$, carrier gas nitrogen, hydrogen detector gas and compressed air for the column) to fractionate the various methyl esters present in the mixture. The various fatty acids present in each organ sample were obtained as peaks in the GLC.

Statistical analysis

The study was based on a completely randomised design. Analysis of variance procedure was used to detect the eflect of diet on the carcass and organ yields (Steel \& Torric, 1960). Fatty acid composition in the organs were not tested statistically due to inadequate organ samples. Rabbit organs had to be composited to obtain required quantity for lipid analysis. Results were therefore, analysed as percetitages.

\section{RESULTS AND DISCUSSION}

\section{Carcass and organ weights}

Result of rabbit carcass and organ weights is shown in Table 3. There were increase or decreases in carcass or organ weights with $\mathrm{PO}$ supplementation but the differences were not significant (lP 0.05$)$. When carcass and organ weights were expressed as a percentage of liveweight, there was no significant (P 0.05 ) differences between treatments, although the intestinal (plus content) and careass weights were slightly decreased and increased, respectively (Table 4). This observation agrees

TABLE 3: EFFECTOF PALM OIL SUPPIEMENTATION ON CARC:ASS AND ORGAN WEIGHTS OF GROWING RABBITS (GRAMS)

\begin{tabular}{llll}
\hline Párameter & $0 \%$ & $\begin{array}{c}\text { Palm oil level* } \\
3 \%\end{array}$ & $5 \%$ \\
\hline Skin & 470 & 490 & 370 \\
Liver & 90 & 100 & 90 \\
Heart & 7 & 6 & 6 \\
Kidney & 20 & 20 & 20 \\
Intestine + contents & 870 & 680 & 670 \\
Head & 390 & 380 & 330 \\
Carcass & 1590 & 1950 & 1550 \\
\hline
\end{tabular}

*Palm oil supplementation not significant $(\mathrm{P}>0.05)$

TABLE 4: EFFECT OF PALM OIL SUPPLEMENTATION ON PERCENTAGE CARCASSA AND ORGAN WEIGHTS OF GROWING RABBITS (\% OF BODYWEIGHT)

\begin{tabular}{llll}
\hline & \multicolumn{2}{c}{ Palm oil level* } \\
Parameter & $0 \%$ & $3 \%$ & $5 \%$ \\
\hline Skin & 13.54 & 12.22 & 11.21 \\
Liver & 2.59 & 2.49 & 2.73 \\
Heart & 0.20 & 0.15 & 0.18 \\
Kidney & 0.58 & 0.50 & 0.61 \\
Intestines + contents & 25.07 & 16.95 & 10.00 \\
Head & 11.24 & 9.48 & 10.00 \\
Carcass & 45.82 & 48.63 & 46.97
\end{tabular}

* Palm oil supplementation not significant $(P>0.05)$. 
TABLE 5: EFFECT OF PALM OIL, SUPPLEMENTATION ON HEART, KIDNEY AND LIVER FATTY ACIDS COMPOSITIONS OF GROWING RABBITS (\% OF TOTAL FATTY ACID)

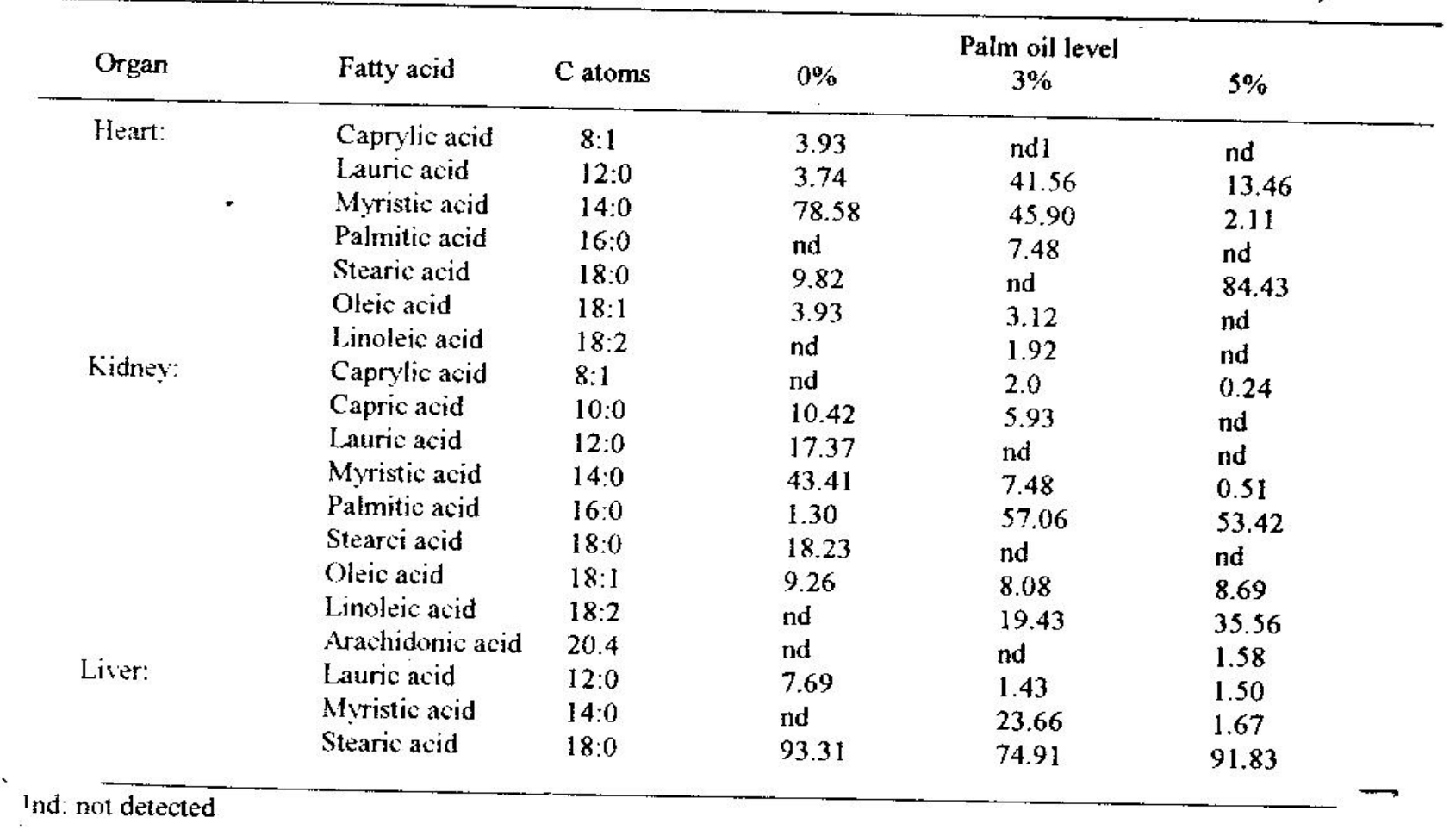

with that of Eshiett et al., (1979), who reported slight but non-significant increase in carcass weight with increase in energy concentration. Iyayi \& Ngodigha (1991) also reported nonsignificant effect of graded levels of palm oil $(0.5$, 1.0 or $1.5 \%$ ) on the weights of liver, heart and kidney of rabbits when fed cassava peel diet. The proportions of liver, kidney and heart to body weight obtained in this study were lower than those reported by lyayi \& Ngodigha (1991) in New Zealand white rabbits. They reported proportions of $0.72,0.70$ and 0.58 for kidney, $0.24,0.23$ and 0.20 for heart and $3.35,2.94$ and 3.11 for liver on diets of $0.5,1.0$ and $1.5 \%$ palm oil, respectively. It is also possible that at the level of inclusion, palm oil may not be able to significantly affect carcass or organ weights. lyeghe and Ekpenyong (1990) in an earlier study, had reported non-significant increase in weight gains in rabbits fed palm oil diets at levels similar to this study. The non-significant effect of palm oil on carcass or organ weights in this study may therefore, substantiate the work of Iyeghe and likpenyong (1990) since carcass and organ weights may be reflected in the total body weight gains.

\section{Organ fatty acid composition}

Results of percentage of individual organ fatty acid (as percentage of total fatty acid in eacı organ) are 1 resented in Table 5 and the trend discussed.

Heart: There were seven fatty acids that were detected either in all treatment groups or singularly in each treatment group (Table 5). The trend of the change in fatty acid composition betweent reatments was not consistent. Percentage of lauric acid in the heart but none was detected in the heart of PO groups. Other fatty acids did not show any consistent pattern. The reasons for the non-detectable levels of caprylic acid in the hearts of rabbits in this study is not known but could be due to the inhibition of the synthesis of caprylic acid by palm oil. The increased level of stearic acid in this study does not agree with the work of Bulhak-Jachymczyk et. al., (1976), who reported decreased level of stearic acid with rapeseed oil. Differences in the source of oil and animal species may have caused the differential results.

Kidney: Kidney fatty acid composition is shown in Table 5. There was increased level of palmitic 


\section{PALM OIL SUPPLEMENTATION FOR GROHING RABITTS}

acid but decreased levels of oleic and myristic acids with $\mathrm{PO}$ diets. Lauric acid was detected in the kidney of the control group but not in the rabbits fed $\mathrm{PO}$ diets. On the other hand, caprylic and linoleic acids were detected in rabbits fed PO diets but not in the control group. Other fatty acids in the kidney did not show any particular or consistent pattern of occurrence (Table 5). The detection of arachidonic acid only in the kidney of the 5\% PO group may indicate that more arachidonic acid could probably be detected in the kidney with further increase of palm oil in the diet.

Liver: There were detectable levels of only Lauric, myristic and stearic acids in the liver of rabbits as shown in Table 5. Lauric and stearic acids levels decreased with PO supplementation. There were detectable levels of myristic acid in the liver of rabbits fed PO diets but none in the control group. The predominant liver fatty acid in all treatment groups was stearic acid. This result agrees with the observation of Kramer et. al., (1975), who reported that the predominant saturated fatty acid in the liver was stearic acid.

There apprars to be a consistent decrease in the level of myristic acid in the three organs with PO supplementation, indicting that there was a decrease in its synthesis in the body. More fatty acids were found in the kidney than the heart or liver. Similar observation have been reported by Rashid et al. (1973) when Swiss albino rats were fed butter fat diet. Depression or feedback inhibition of hepatic synthesis of fatty acids may have caused the relatively fewer number of fatty acids found in the liver (Bortz, 1967; Sabine et al., 1969; Haghighi-Rad and Polin, 1983). Althoug, only oils with high levels of linoleic acid are reported to exhibit negative feedback meachanism (Sabine et al., 1969), palm oil which is low in linoleic acid, (about $9.9-11.2 \%$ ) seems to exhibit similar effect in this study with rabbits.

Mortality

Three rabbits fed on the control diet died between the first and second week of the experiement. Post mortem examination showed that death was as a result of septicaemia. It is possible that rabbits on control diet did not have adequate immunity when predisposed to septicaemic conditions as against those fed PO diets. Development of immune response by increasing antibody formation as a result of fat inclusion in diets have been reported in rabbits (Jezkova and Petz, 1976). Palm oil also contain some quantities of unsaturated fatty acids, which are known to have bactericidal effect or a stabilizing effect on bacterial population in the gastrointestinal tract of rabbits (Fuller and Moore, 1971). The death of one rabbit on the $5 \%$ PO diet due to paralysis resulting in urinary incontinence was not related to the diet.

\section{CONCLUSION}

The results of this study showed that there was a non significant ( $P$ 0.05) increase in carcass or organ weights with palm oil supplementation. Although the levels of organ fatty acid were not tested, palm oil supplementation seems to affect fatty acid composition but there was no consistent pattern for most of the fatty acids except for myristic acid level, which was depressed in the three organs of rabbits fed PO diets. The non significant effect of palm oil in this study may be due to the fact that all diets were made to be sionitrogenous and isocaloric (TAble 1), thereby cancelling the effect of the high caloric value of PO in the diet (Table 2). The observed mortality due to septicaemia in the control group and the known fact that PO enlances the development of immunity and its bacteriacidal effect calls for further study in this regard. The cause of paralysis and urinary incontinence in one of the rabbits fed $5 \%$ diet was due to spinal injury and cannot be attributed to the diet fed.

\section{ACKNOWLEDGEMENTS}

The authors wish to acknowledge the contributions , it the folowing: Mr. W. T. Okoye and staff of the Nigerian Stored Products Research Institute (NSPRI), Ibadan; Prof. A. U. Osagie (Biochemistry Dept. University of Benin) and management and staff of the Biochemistry Division, Nigerian Institute for Oil Palm Research (NIFOR), Benin for their assistance during the course of this work.

\section{RIFIRINCES}

AOAC (1980). Aswociation of Official Aralytical

Chemists. Oricial methods of analysis of the 
association of analytical chemists, 13th ed., Washington, D.C.

REYNEN, C.A. (1988). Dietary fat level and growth performance by rabbits. J. App.Rrabbit Res. 11: 21 - 24.

BORTZ, M.W. (1967). Fat and cholesterol synthesis. Biochem. Biophys. Acta. 137: 533.

BULHAK-JACHYMCZYK, B., KUCHARCZYK, B. and OLSZEWSKZ-KACZNSKA, I. (1976). Effect of dietary erucic acid on the fatty acid composition of the heart and liver phospholipids in rats. Nutr. Abstr. Rev. 46: 845.

ES. IETT, N., OMOLE, T.A. and ADEGBOLA, A.A (1979). Crude protein and energy requirments of rabbits in the tropics. Nig. J. Agric. Sci. 1: 113 117.

FULLER, R. and MOORE, J.H. (1971). The effect on rabbit intestinal microflora of diets which influence serum cholesterol levels. Lab. Anim. 5: 25 - 30.

HAGHIGHI-RAD, F. and POLIN, D. (1983), Lipid: the unidentified factor for alleviating fatty liver syndrome. Nutr. Abstr. Rev. 53: 172.

IYAYI, E.A. and NGODIGHA, E. (1991).

Performance and organ weights of rabbits fed diets with graded levels of cassava peel and palm oil. J. Appl. Rabbit Res. 14:152-154.

IYEGHE,G.T. and EKPEYONG, T.E.(1990). Effect of paim oil supplementation on growth performance and nutrient digestibility by grower rabbits. Trop. Anim Prod. Invest. 1: 46 - 52.

JAMES. A.T. (1960). Qualitative and quantitative determination of the fatty acids by Gas Liquid Chromatography. Methods of Biochemical Analysi. Inter Science Publishers Inc., New York, Vol. 8: 7 19.

JENXKOVAN, Z. and PETZ, R. (1976). Effect of experimental stress on immunological reactions in experimental atherosclerosis of rabbits. Nutr. Abstr. Rev. 46: 235

KRAMER, J.K.G., FRIEND, D.W, and HULAN, H.W. (1975). Lipid changes in tissues of young boards fed rapeseed oil or corn oil. Nutr. Metab. 19: $279-290$.

PUTHZHATH, D. and ALAMELA, V. (1977). Effect of dietary fat on oxidative phosphorylation and fatty acid profile o rat liver mitochondria. $J$. Nutr. 107: $1621-1631$.

RASHID, J., SIAL, M.A. and SIAL, M.B. (1973). Influence of various dietary fats on tissue lipid picture of rats. Nutr. Abstr. Rev. 4: 297.

SELL, L.J. and OWTNGS, J.W. (1981).

Supplemental fat and metabolizable energy-tonutrient ratios for growing turkeys, $J$. Poult. Sci. 60: $2293-2309$.
STEEL, R.N and TORRIE, J.H. (1960). Principles and procedures of statistics. 1 st ed. McGraw Hill Book Co. Inc. New York.

VODOVAR, N., DESNOYERS, F., CLUZAN, R., MORSON, A.M. and LEVILLIAN, R. (1973).

Accumulation of lipids in the myocardium of rats given rapeseed oil in their diet. Nutr. Abstr. Rev. 43: 224.

WILLIAM, M.A., CHU, L.C., MCINTOSH, D.J. and HINCENBERGS, I. (1968). Effects of dietary fat level on pantothenate depletion and liver fatty acid imbalance. J. Nutr. 94: 377 - 382.

*Current Address: Department of Animal Production, Ogun State University, P.M.B. 2002, Ago-Iwoye, Ogun State. 